\title{
3. Factors explaining youth unemployment and early job insecurity in Europe
}

\section{Maria Karamessini, Maria Symeonaki, Glykeria Stamatopoulou and Dimitris Parsanoglou}

\section{INTRODUCTION}

Unemployment and difficulties integrating young people into the labour market are widely recognized to represent major challenges for the European Union, which is currently facing multiple tasks in this area. Despite ample consideration and suggested convergence policies between EU member states, youth unemployment and early job insecurity remain extensive in many European countries, irrespective of the impact of the financial crisis on their economies.

Much action has been taken to decrease youth unemployment, but evidence shows persistently high levels in many European countries, especially since the outbreak of the crisis (Karamessini et al., 2016b). According to Eurostat, ${ }^{1}$ youth unemployment rates in the EU-28 exceeded 15 per cent in 21 countries in 2015 . In the same year there was extremely wide variation in youth unemployment rates across Europe, ranging from 7.2 per cent in Germany and 8.8 per cent in Iceland to 48.3 per cent in Spain and 49.8 per cent in Greece. The problem is evidently far more acute and persistent in some countries than in others. Spain, Greece, Croatia, Italy, Portugal and Cyprus are the countries most affected by the economic crisis, particularly in terms of youth unemployment.

Looking at gender differentiations, women exhibited a distinctly higher unemployment rate up until 2007, but after 2008 - as the crisis substantially affected the 'male' occupations - male and female unemployment

1 http://ec.europa.eu/eurostat/statistics-explained/index.php/File:Youth_unemployment_ figures,_2007-2016_(\%25)_T1.png (accessed 10 May 2018). 
rates appeared to converge (Symeonaki and Filopoulou, 2017). In 2015 the unemployment rates of young people (aged 15-24) showed a gender difference of two percentage points (females: 19.5 per cent; males: 21.1 per cent), whereas in 2008 the youth unemployment rates for males and females in the EU-28 were both lower and almost equal (females: 15.8 per cent; males: 16.0 per cent). However, there are many differences at country level, ranging from cases where young males have lower youth unemployment rates (the extreme example is Greece, where the difference amounts to about ten percentage points: females: 55.0 per cent; males: 45.2 per cent) to countries where the opposite is the case (e.g., Ireland: females: 17.6 per cent; males: 23.6 per cent).

In addition to the unemployment rate, the NEET rate (individuals who are not in employment, education or training) is another important indicator of early job insecurity. Between 2008 and 2015 in the EU-28, the NEET rate increased by 1.1 percentage points for individuals aged 15-24 and by 2.4 percentage points for individuals aged $20-34$, according to Eurostat. ${ }^{2}$ Over the same period a significant decrease of 3.4 percentage points was recorded in the share of young individuals who were employed and had left (formal and non-formal) education and training. This loss was evened out by a rise in the percentage of young people aged between 20 and 34 who were in some kind of education or training, considering both those who spent their time entirely in education and training and those who combined it with employment. This development may reveal a growing need for young individuals to attain higher skills or qualifications because of increased competition in the labour market, but it might likewise suggest a decrease in more traditional full-time employment opportunities during the economic crisis. It is also worth mentioning that a large share of the inactive NEETs in several countries is composed of young females. Young women thus seem to have higher probabilities of being inactive for longer periods than their male counterparts, mostly because of family responsibilities (Plantenga et al., 2013; Sigle-Rushton and Perrons, 2013). Greece and Italy are the two countries that recorded the highest NEET rates in the year 2015. In the same year in ten out of 28 EU member states, the proportion of young female NEETs aged 20-34 was at least ten percentage points higher than the corresponding share for young males.

Several studies have dealt with youth unemployment and the divergences between EU member states (see, amongst others, Chung et al.,

2 http://ec.europa.eu/eurostat/statistics-explained/index.php/Statistics_on_young_people _neither_in_employment_nor_in_education_or_training\#Young_people_neither_in_employ ment_nor_in_education_or_training (accessed 10 May 2018). 
2012; Eichhorst et al., 2013; Eurofound, 2014). Many attempts have also been made to present patterns and features or factors - individual and/ or non-individual - such as Gross Domestic Product (GDP) growth to explain youth unemployment (Brada et al., 2014; Eichhorst et al., 2013; O'Reilly et al., 2015). Countries' labour market characteristics are considered in O'Higgins (2012), where labour market flexibility is said to have played a significant role in the increase in youth unemployment during the economic crisis. On the other hand, Bell and Blanchflower (2011) argue that lack of demand is the key factor driving the rise in youth unemployment. Individual-level factors explaining youth unemployment rates and inactivity are provided for the year 2013 in Karamessini et al. (2016b) using Eurostat Labour Force Survey (EU-LFS) data, whereas in Symeonaki et al. (2017) individual-level factors such as gender, educational level achieved and labour market state one year before the survey are examined as factors influencing youth unemployment and inactivity for the year 2014. The impact of the crisis on youth unemployment (Bell and Blanchflower, 2011; Bruno et al., 2014; Chung et al., 2012; OECD, 2010; O'Higgins, 2010, 2012; Van Ours, 2015) and on school-to-labour-market transitions and labour market flows has also been studied (Karamessini et al., 2016a, 2016b; Symeonaki et al., forthcoming a, forthcoming b).

This chapter investigates individual-level factors explaining youth unemployment and inactivity. More specifically, a multinomial logistic regression (MLR) model is applied using existing data sources so as to provide a deeper understanding of youth unemployment and inactivity and their relationship with a number of sociodemographic variables measuring individual characteristics such as gender, educational attainment, nationality, age and the respective region's degree of urbanization for the years 2008 and 2015. Parental education is also examined for those who are still living in the parental household.

\section{DATA AND METHODOLOGY}

In order to identify the individual-level factors that increase the risk of young people being unemployed or inactive, we use raw data drawn from the EU-LFS for the years 2008 (i.e., the beginning of the crisis) and 2015 (i.e., the most recent year for which data were available) and covering the nine European countries participating in the NEGOTIATE project: Bulgaria, the Czech Republic, Germany, Greece, Norway, Poland, Spain, Switzerland and the United Kingdom.

MLR models are commonly used in the literature to examine or analyse in detail the determinants of unemployment (Dănăcică, 2015; Msigwa and 
Kipesha, 2013). The MLR method is generally used to model the outcome of a nominal variable, whereby the log odds of the outcomes are modelled as a linear combination of the predicted variables; therefore, it can be used whenever we want to predict categorical outcomes from continuous and categorical predictors. In this chapter we develop a prediction method for identifying high-risk groups for unemployment and inactivity. Predictor variables include gender, educational attainment, nationality, age groups (15-19, 20-24 and 25-29), the respective region's degree of urbanization, and parental education for individuals aged between 15 and 29 who are still living in the parental household. We thus seek to identify which sociodemographic factors influence the labour market outcomes of individuals by country and we create profiles of those people who are most likely to be at high risk of unemployment or inactivity.

We specify the baseline comparison group as being in employment so that all parameters in the model are interpreted in reference to this state. We choose employment as the reference category because it is assumed to be the 'desired' category to which others would normally be compared. In this way the MLR can assess the odds of being unemployed versus being employed and the odds of being inactive versus being employed, taking into account the selected sociodemographic characteristics.

More specifically, we are interested in the three categories of labour market states of the individual (employment, unemployment and inactivity). We consider the existence of three unobserved continuous variables, each of which can be thought of as the propensity towards a labour market state, with higher values corresponding to higher probabilities of being in the respective state. We specify the baseline comparison group using the variable corresponding to the International Labour Organization (ILO) work status of the individual (ILOSTAT $=1$, related to employment). The results reveal the Relative Risk Ratios (RRR) of being unemployed (versus employed) and inactive (versus employed) for:

- Low- and medium-educated individuals compared to highly educated individuals, ${ }^{3}$

- Females compared to males, ${ }^{4}$

- Non-native individuals compared to natives, ${ }^{5}$

- Individuals belonging to the age groups 15-19 and 20-24 compared to individuals aged $25-29,{ }^{6}$

\footnotetext{
Variable: HATLEV1D.

Variable: SEX.

Variable: NATIONAL.

Variable: AGE.
} 
- Individuals living in rural areas (thinly populated area) or towns and suburbs (intermediate density area) compared to those living in cities (densely populated area). ${ }^{7}$

Parental education is considered separately as a predicting factor for the individual's unemployment or inactivity because EU-LFS is a household survey and parental education (level of education of father or mother) is only measured if the father or mother lives in the same household as the respondent.

\section{RESULTS}

When one chooses to analyse data using MLR, a share of the process involves testing to make sure that the data actually have the appropriate characteristics for such an analysis. In other words, this kind of analysis is only valid and suitable if the data meet the assumptions that are required for MLR to provide reliable results. Preliminary analysis was thus performed to check the validity of these assumptions. Cross-tabulation, chisquare tests and likelihood ratio tests revealed that gender, educational attainment, nationality, age, the respective region's degree of urbanization and parental education are not independent of the labour market state of the individual in most countries. The results also reveal that the variables do all have a significant predictive role in those countries, therefore all required assumptions are valid and MLR is appropriate.

The analysis was performed for the EU-LFS data sets for the years 2008 and 2015. The variables used were Level of education (low: lower secondary; medium: upper secondary; high: third level); Gender (male, female); Labour market state of the individual; ${ }^{8}$ Nationality; ${ }^{9}$ Degree of urbanization (rural, towns and suburbs, cities) ${ }^{10}$ Age categories (15-19, 20-24, 25-29); Level of education of father and Level of education of mother (low: lower secondary; medium: upper secondary; high: third level). ${ }^{11}$

Below we present results from the MLR analyses for 2008 and 2015 for

7 Variable: DEGURBA.

8 Variable: ILOSTAT's values are: $1=$ Employed, $2=$ Unemployed, $3=$ Inactive and $4=\mathrm{In}$ compulsory military service. For the purposes of this analysis the third and fourth categories were merged.

9 NATIONAL is recoded into a new variable with the values $0=$ national and $1=$ non-national.

10 DEGURBA (degree of urbanization) is not available for Norway 2008 or Switzerland 2008.

11 HATLFATH and HATLMOTH are not available for Norway 2008 and 2015, or for Switzerland 2008 and 2015. 
each country. We have classified the examined countries in four groups based on geographical and economic characteristics: post-socialist EU member states from Eastern Europe, represented by Bulgaria, the Czech Republic and Poland; EU member states with relatively strong economies from Western Europe, comprised of Germany and the United Kingdom; ${ }^{12}$ EU member states with relatively weak economies from Southern Europe, represented by Greece and Spain; and non-EU member states with relatively strong economies, comprised of Norway and Switzerland.

In Bulgaria (Table 3.1) the analysis revealed that educational attainment was an important factor influencing the propensity of young people towards unemployment both in 2008 and 2015. Lower-educated individuals had an almost ten times higher likelihood of being unemployed than highly educated people, whereas medium-educated individuals were more than twice as likely to be unemployed as opposed to employed compared to highly educated people - for both years we studied. A key factor identified here was the specific age group of the individuals; in fact, the RRR of being unemployed was almost 34 times higher for younger individuals (15-19) than for individuals aged 25-29 both for 2008 and 2015. We must note here that unemployed individuals are by definition those who are not employed, are not in education or training, and are in search of work. ${ }^{13}$ This very high RRR denotes, therefore, that the young unemployed are far more likely to belong to the younger age group (15-19) than to the age group 25-29. Another important difference that emerged was the increase in the likelihood of being unemployed when a young person was aged 20-24 compared to those aged 25-29: this RRR was more than 2.5 times higher in 2015 than in 2008. In the year 2015 young men were two times more at risk of being unemployed than young women, whereas in 2008 the RRR of young women being unemployed was almost 2.5 times higher than that of men. Moreover, the situation was evidently reversed in the way the degree of urbanization influenced the unemployment of young individuals. In 2015 living in cities represented an advantage for young people where employment was concerned, as opposed to living in thinly populated areas or areas with an intermediate degree of urbanization. Education played an important role as to whether a young individual would be inactive or employed in 2008, but it played an even more significant role in 2015. The situation had also deteriorated for the younger individuals concerning inactivity, since their likelihood of being inactive was almost two times higher in 2015 both for those aged 15-19 and those aged 20-24. In 2015

12 For the reference period.

13 http://ec.europa.eu/eurostat/statistics-explained/index.php/Glossary:Youth_unem ployment (accessed 9 May 2018). 
Table 3.1 Relative risk ratios for individuals aged 15-29 (unemployed vs employed, and inactive vs employed), Bulgaria, Czech Republic, Poland: 2008 and 2015

\begin{tabular}{|c|c|c|c|c|c|c|}
\hline & Factors & Categories & Unemployed & $\begin{array}{l}\text { Std. } \\
\text { errors }\end{array}$ & Inactive & $\begin{array}{l}\text { Std. } \\
\text { errors }\end{array}$ \\
\hline \multirow{7}{*}{$\begin{array}{l}\text { Bulgaria, } \\
2008\end{array}$} & \multirow{5}{*}{$\begin{array}{l}\text { Level of } \\
\quad \text { education } \\
\text { Gender } \\
\text { Age groups }\end{array}$} & Low & $9.6 ?$ & 0.172 & 3.99 & 0.191 \\
\hline & & Medium & $2.313 * * *$ & 0.156 & 1.559 & 0.166 \\
\hline & & Female & $2.472 * * *$ & 0.079 & - & - \\
\hline & & $15-19$ & $34.479 * * *$ & 0.131 & $2.982 * * *$ & 0.129 \\
\hline & & $20-24$ & $3.513^{* * *}$ & 0.090 & $1.495 * * *$ & 0.156 \\
\hline & \multirow{2}{*}{$\begin{array}{l}\text { Degree of } \\
\text { urbanization }\end{array}$} & Rural areas & $0.760 * * *$ & 0.082 & - & - \\
\hline & & $\begin{array}{c}\text { Towns and } \\
\text { suburbs }\end{array}$ & $0.695^{\prime}$ & 0.157 & - & - \\
\hline \multirow{7}{*}{$\begin{array}{l}\text { Bulgaria, } \\
2015\end{array}$} & \multirow{5}{*}{$\begin{array}{l}\text { Level of } \\
\quad \text { education } \\
\text { Gender } \\
\text { Age groups }\end{array}$} & Low & $9.900 *$ & 0.174 & $4.255^{* * *}$ & 0.169 \\
\hline & & Medium & 2.724 & 0.146 & $2.164 * * *$ & 0.139 \\
\hline & & Female & $0.478 * * *$ & 0.089 & $0.546 * * *$ & 0.137 \\
\hline & & $15-19$ & $34.890 * * *$ & 0.190 & $6.921 * * *$ & 0.109 \\
\hline & & $20-24$ & $8.967 * * *$ & 0.191 & $3.935 * * *$ & 0.108 \\
\hline & \multirow{2}{*}{$\begin{array}{l}\text { Degree of } \\
\quad \text { urbanization }\end{array}$} & Rural areas & $1.497 * * *$ & 0.106 & $2.090 * * *$ & 0.169 \\
\hline & & $\begin{array}{c}\text { Towns and } \\
\text { suburbs }\end{array}$ & $1.282 * * *$ & 0.117 & $2.071 * * *$ & 0.190 \\
\hline \multirow{8}{*}{$\begin{array}{l}\text { Czech } \\
\text { Republic, } \\
2008\end{array}$} & \multirow{6}{*}{$\begin{array}{l}\text { Level of } \\
\quad \text { education } \\
\text { Gender } \\
\text { Nationality } \\
\text { Age groups }\end{array}$} & Low & $6.582 * * *$ & 0.060 & $7.962 * * *$ & 0.215 \\
\hline & & Medium & - & - & $1.200 * * *$ & 0.110 \\
\hline & & Female & $2.801 * * *$ & 0.026 & $1.464 * * *$ & 0.057 \\
\hline & & Non-national & $0.515^{* * *}$ & 0.113 & $0.552 *$ & 0.269 \\
\hline & & $15-19$ & $19.671 * * *$ & 0.049 & $2.115 * * *$ & 0.103 \\
\hline & & $20-24$ & $3.720 * * *$ & 0.029 & $2.045^{* * *}$ & 0.064 \\
\hline & \multirow{2}{*}{$\begin{array}{l}\text { Degree of } \\
\quad \text { urbanization }\end{array}$} & Rural a & $0.772 * * *$ & 0.030 & - & - \\
\hline & & $\begin{array}{c}\text { Towns and } \\
\text { suburbs }\end{array}$ & 0.84 & 0.034 & - & - \\
\hline \multirow{6}{*}{$\begin{array}{l}\text { Czech } \\
\text { Republic, } \\
2015\end{array}$} & \multirow{6}{*}{$\begin{array}{l}\text { Level of } \\
\quad \text { education } \\
\text { Gender } \\
\text { Nationality } \\
\text { Age groups }\end{array}$} & Low & $0.201 * * *$ & 0.139 & $1.767 * * *$ & 0.115 \\
\hline & & Medium & $1.209 * * *$ & 0.093 & - & - \\
\hline & & Female & $0.345 * * *$ & 0.071 & $0.589 * * *$ & 0.125 \\
\hline & & Non-national & $1.618 * * *$ & 0.279 & - & - \\
\hline & & $15-19$ & $29.076^{* * *}$ & 0.145 & $17.880 * * *$ & 0.112 \\
\hline & & $20-24$ & $7.013 * * *$ & 0.141 & $6.882 * * *$ & 0.109 \\
\hline \multirow{6}{*}{$\begin{array}{l}\text { Poland, } \\
2008\end{array}$} & \multirow{6}{*}{$\begin{array}{l}\text { Level of } \\
\quad \text { education } \\
\text { Gender } \\
\text { Nationality } \\
\text { Age groups }\end{array}$} & Low & $9.544 * * *$ & 0.057 & $1.856^{* * *}$ & 0.094 \\
\hline & & Medium & $2.680 * * *$ & 0.042 & $1.243 * * *$ & 0.059 \\
\hline & & Female & $2.247 * * *$ & 0.026 & $1.470 * * *$ & 0.043 \\
\hline & & Non-national & $2.801 * * *$ & 0.495 & - & - \\
\hline & & $15-19$ & $19.484 * * *$ & 0.047 & $1.830 * * *$ & 0.096 \\
\hline & & $20-24$ & $3.350 * * *$ & 0.029 & $2.149 * * *$ & 0.047 \\
\hline
\end{tabular}


Table 3.1 continued

\begin{tabular}{|c|c|c|c|c|c|c|}
\hline & Factors & Categories & Unemployed & $\begin{array}{l}\text { Std. } \\
\text { errors }\end{array}$ & Inactive & $\begin{array}{l}\text { Std. } \\
\text { errors }\end{array}$ \\
\hline \multirow{10}{*}{$\begin{array}{l}\text { Poland, } \\
2015\end{array}$} & \multirow{2}{*}{$\begin{array}{l}\text { Degree of } \\
\quad \text { urbanization }\end{array}$} & Rural areas & $0.696^{* * *}$ & 0.028 & $1.253 * *$ & 0.048 \\
\hline & & $\begin{array}{c}\text { Towns and } \\
\text { suburbs }\end{array}$ & $0.855^{* * *}$ & 0.041 & $1.176^{* * *}$ & 0.070 \\
\hline & \multirow{3}{*}{$\begin{array}{l}\text { Level of } \\
\text { education } \\
\text { Gender }\end{array}$} & Low & $0.110 * * *$ & 0.049 & $0.281^{* * *}$ & 0.075 \\
\hline & & Medium & $0.519 * * *$ & 0.034 & $0.757 * * *$ & 0.052 \\
\hline & & Female & $0.352 * * *$ & 0.026 & $0.416^{* * *}$ & 0.038 \\
\hline & Nationality & Non-national & $0.436 * * *$ & 0.271 & - & - \\
\hline & \multirow[t]{2}{*}{ Age groups } & $15-19$ & $32.437 * * *$ & 0.050 & $14.758 * * *$ & 0.078 \\
\hline & & $20-24$ & $7.660 * * *$ & 0.048 & $6.703 * * *$ & 0.073 \\
\hline & \multirow{2}{*}{$\begin{array}{l}\text { Degree of } \\
\quad \text { urbanization }\end{array}$} & Rural areas & $1.362 * * *$ & 0.029 & $1.767 * * *$ & 0.045 \\
\hline & & $\begin{array}{c}\text { Towns and } \\
\text { suburbs }\end{array}$ & $1.087 * * *$ & 0.035 & $1.572 * * *$ & 0.054 \\
\hline
\end{tabular}

Note: ${ }^{* * *} \mathrm{p}<0.0001,{ }^{* *} \mathrm{p}<0.001,{ }^{*} \mathrm{p}<0.01$ (only relative risk ratios corresponding to statistically significant coefficients are included).

Source: EU-LFS data

being male and living in rural areas or towns/suburbs increased the risk of being inactive. Nationality was not included in the model because of the very small percentage of non-nationals in the Bulgarian sample.

In the Czech Republic (Table 3.1) the most important factor influencing unemployment appeared to be age. Younger individuals (15-19) were more likely to be at risk of unemployment than those aged 25-29. This difference became even more evident during the years of the crisis, with younger individuals exhibiting a more than 1.5 times higher propensity towards unemployment in 2015 than in 2008. Low-educated youngsters had a higher propensity towards unemployment in 2008 than their highly educated peers, which was not the case in 2015. Important differences between 2008 and 2015 also emerged in the areas of gender and nationality; in 2008 young women had a 2.8 times higher RRR of being unemployed than men, while in 2015 young men had a 2.9 times higher RRR of being unemployed. On the other hand, natives were more vulnerable to youth unemployment than non-natives in 2008, while in 2015 this tendency was reversed, with non-natives having a 1.6 times higher RRR of being unemployed. In 2008 rural areas and towns/suburbs were in a better situation than cities with respect to youth unemployment, whereas in 2015 the degree of urbanization did not play a predictive role for youth unemployment. Finally, the role of education was significant in 2015 with 
respect to youth inactivity, but not as significant as it had been in 2008; the role of gender in inactivity was reversed, and the situation of the youngest age group had weakened substantially by 2015 .

In Poland (Table 3.1) education seemed to influence the likelihood both of being unemployed and of being inactive in 2008, although the RRR of being unemployed and not employed was a lot higher than that of being inactive and not employed. This was not the case in 2015, where lower-educated young individuals did not have higher chances of being unemployed or inactive. Young women's chances of being unemployed or inactive were considerably higher than those of men in 2008, which was no longer the case in 2015, where the respective RRR was equal to 0.352 . Non-natives' propensity to be unemployed decreased considerably between the two years, whereas the RRR of the youngest age group to be unemployed and not employed or inactive increased substantially. The role of the degree of urbanization was reversed in 2015, with young individuals living in rural areas exhibiting slightly higher risks of unemployment or inactivity than those living in cities.

When it comes to the second group of countries and more specifically to Germany (Table 3.2), all factors had a predictive role in 2008, with the level of education and age seemingly having the highest impact on the propensity of young individuals to be unemployed or inactive. More particularly, in 2008 the RRR of being unemployed was almost 5 times higher for those with low education and almost 3.6 times higher for those who were medium educated compared to the highly educated; similarly, in 2008 the RRR was 1.278 for non-natives compared to natives and 1.344 for females compared to males. Additionally, if a young German belonged to the 15-19 or 20-24 age group, his/her chances of being unemployed were almost 6.7 and 1.7 times higher, respectively, than if he/she was aged 25-29. Moreover, lower degrees of urbanization had a positive effect on youth unemployment in 2008, whereas lower education had a negative effect on youth inactivity in the same year. In 2015 the direction of the effect of each factor except age was reversed with respect to youth unemployment; high education did not lead to higher likelihoods of being employed, young women and non-natives were in a better situation compared to men and natives, respectively, and cities were in a better situation when compared to areas with a lower degree of urbanization. On the other hand, the situation deteriorated for the younger categories, with the first age group (15-19) having a 7.870 higher RRR of being unemployed, and the second group (20-24) having a 3.771 higher RRR than those in the third age group (25-29). The propensity of the youngest age group towards inactivity was much higher, while lower-educated individuals and young men also had a greater RRR of being inactive. RRRs close to 1 
Table 3.2 Relative risk ratios for individuals, 15-29 (unemployed vs employed, and inactive vs employed), Germany and United Kingdom: 2008 and 2015

\begin{tabular}{|c|c|c|c|c|c|c|}
\hline & Factors & Categories & Unemployed & $\begin{array}{l}\text { Std. } \\
\text { Error }\end{array}$ & Inactive & $\begin{array}{l}\text { Std. } \\
\text { Error }\end{array}$ \\
\hline \multirow{8}{*}{$\begin{array}{l}\text { Germany, } \\
2008\end{array}$} & \multirow{6}{*}{$\begin{array}{l}\text { Level of } \\
\quad \text { education } \\
\text { Gender } \\
\text { Nationality } \\
\text { Age groups }\end{array}$} & Low & $4.924 * * *$ & 0.166 & $4.814 * * *$ & 0.138 \\
\hline & & Medium & $3.659 * * *$ & 0.155 & $1.905^{* * *}$ & 0.124 \\
\hline & & Female & $1.344 * * *$ & 0.053 & - & - \\
\hline & & Non-national & $1.278 * * *$ & 0.095 & - & - \\
\hline & & $15-19$ & $6.737 * * *$ & 0.090 & $0.567 * * *$ & 0.170 \\
\hline & & $20-24$ & $1.725 * * *$ & 0.069 & - & - \\
\hline & \multirow{2}{*}{$\begin{array}{l}\text { Degree of } \\
\quad \text { urbanization }\end{array}$} & Rural areas & $0.574 * * *$ & 0.085 & - & - \\
\hline & & $\begin{array}{c}\text { Towns and } \\
\text { suburbs }\end{array}$ & $0.792 * * *$ & 0.059 & - & - \\
\hline \multirow{8}{*}{$\begin{array}{l}\text { Germany, } \\
2015\end{array}$} & \multirow{6}{*}{$\begin{array}{l}\text { Level of } \\
\quad \text { education } \\
\text { Gender } \\
\text { Nationality } \\
\text { Age groups }\end{array}$} & Low & $0.296 * * *$ & 0.038 & $1.573 * * *$ & 0.077 \\
\hline & & Medium & $0.562^{* * *}$ & 0.034 & $0.764 * * *$ & 0.073 \\
\hline & & Female & $0.768 * * *$ & 0.017 & $0.600 * * *$ & 0.040 \\
\hline & & Non-national & $0.636^{* * *}$ & 0.028 & - & - \\
\hline & & $15-19$ & $7.870 * * *$ & 0.028 & $14.917 * * *$ & 0.063 \\
\hline & & $20-24$ & $3.771 * * *$ & 0.025 & $27.121 * * *$ & 0.060 \\
\hline & \multirow{2}{*}{$\begin{array}{l}\text { Degree of } \\
\quad \text { urbanization }\end{array}$} & Rural areas & $1.797 * * *$ & 0.024 & $1.119^{*}$ & 0.057 \\
\hline & & $\begin{array}{c}\text { Towns and } \\
\text { suburbs }\end{array}$ & $1.484 * * *$ & 0.020 & $1.127^{* *}$ & 0.043 \\
\hline \multirow{8}{*}{$\begin{array}{l}\text { UK, } \\
2008\end{array}$} & \multirow{6}{*}{$\begin{array}{l}\text { Level of } \\
\quad \text { education } \\
\text { Gender } \\
\text { Nationality } \\
\text { Age groups }\end{array}$} & Low & $4.528 * * *$ & 0.050 & $4.239 * * *$ & 0.078 \\
\hline & & Medium & $2.036 * * *$ & 0.047 & $1.504 * * *$ & 0.076 \\
\hline & & Female & $1.650 * * *$ & 0.028 & $0.836^{* * *}$ & 0.046 \\
\hline & & Non-national & $0.164 * * *$ & 0.045 & - & - \\
\hline & & $15-19$ & $4.693 * * *$ & 0.037 & $3.269 * * *$ & 0.063 \\
\hline & & $20-24$ & $1.798 * * *$ & 0.037 & $2.100 * * *$ & 0.060 \\
\hline & \multirow{2}{*}{$\begin{array}{l}\text { Degree of } \\
\quad \text { urbanization }\end{array}$} & Rural areas & $0.739 * * *$ & 0.044 & $0.579 * * *$ & 0.079 \\
\hline & & $\begin{array}{c}\text { Towns and } \\
\text { suburbs }\end{array}$ & $0.676^{* * *}$ & 0.041 & $0.768 * * *$ & 0.065 \\
\hline \multirow{8}{*}{$\begin{array}{l}\text { UK, } \\
2015\end{array}$} & \multirow{6}{*}{$\begin{array}{l}\text { Level of } \\
\quad \text { education } \\
\text { Gender } \\
\text { Nationality } \\
\text { Age groups }\end{array}$} & Low & $0.202 * * *$ & 0.076 & $0.667 * * *$ & 0.124 \\
\hline & & Medium & $0.489 * * *$ & 0.067 & $0.544 * * *$ & 0.118 \\
\hline & & Female & $0.678 * * *$ & 0.046 & $0.594 * * *$ & 0.079 \\
\hline & & Non-national & $0.569 * * *$ & 0.073 & $0.746 * * *$ & 0.109 \\
\hline & & $15-19$ & $7.831^{* * *}$ & 0.061 & $1.735^{* * *}$ & 0.109 \\
\hline & & $20-24$ & $4.218 * * *$ & 0.025 & $2.073 * * *$ & 0.093 \\
\hline & \multirow{2}{*}{$\begin{array}{l}\text { Degree of } \\
\quad \text { urbanization }\end{array}$} & Rural areas & $1.294 * * *$ & 0.073 & - & - \\
\hline & & $\begin{array}{c}\text { Towns and } \\
\text { suburbs }\end{array}$ & $1.321 * * *$ & 0.053 & - & - \\
\hline
\end{tabular}

Note: ${ }^{* * *} \mathrm{p}<0.0001, * * \mathrm{p}<0.001, * \mathrm{p}<0.01$ (only relative risk ratios corresponding to statistically significant coefficients are included).

Source: EU-LFS data 
(1.119 and 1.127, respectively, for rural areas and towns/suburbs) in 2015 indicate that the degree of urbanization did not affect the propensity of young individuals towards inactivity.

In the United Kingdom in 2008 the expected risk of being unemployed was about 4.5 times higher for the low educated ( $R R R=4.528)$, while it was more than twice higher for the medium educated. Young females had a higher likelihood of being unemployed than men $(R R R=1.650)$ and a lower likelihood of being inactive $(\mathrm{RRR}=1.436)$. The low and medium educational level of young people also played a significant role in their odds of being left out of the labour market, with the odds being almost 4 times higher for low-educated youth and almost 1.5 times higher for medium-educated youth. Age played a significant role in the case of both unemployment and inactivity in 2008, whereas in the same year cities were in a worse position than areas with a lower degree of urbanization. In 2015 the role of education was reversed, and lower and medium educational attainment of young individuals did not negatively affect their chances of being employed and not unemployed or inactive. Females had lower likelihoods of being unemployed or inactive than males, while age was again an important determinant for unemployment and inactivity. Young individuals living in cities had slightly better chances in 2015 of being employed compared to those living in rural areas or towns/suburbs. Furthermore, non-natives had better possibilities in 2015 than natives of being employed and not unemployed or inactive.

In Greece (Table 3.3) low- and medium-educated young individuals were more likely to be unemployed than employed in 2008 and even more so in 2015. The RRR of being unemployed and not employed was almost 2.5 times higher for young women than for young men in 2008, and it was almost twice as high in 2015 . Being non-native had exactly the same effect on the propensity towards unemployment in 2008 and 2015, with non-natives having better chances of being employed than natives. Areas with a lower degree of urbanization were in a better situation both in 2008 and 2015. The analysis also revealed a significantly worse position for the younger age groups in 2008 and even worse again in 2015 compared to those aged 25-29. When inactivity is considered, lower-educated individuals had higher chances of being inactive than the highly educated in 2015 compared to 2008 , while women were still more likely to be inactive than men. The degree of urbanization did not play a predictive role for inactivity: the respective RRRs were close to 1 .

Looking now at Spain (Table 3.3), in 2008 gender and nationality seemed to play a predictive role regarding the risk of being unemployed, with women and natives having higher chances of being unemployed than men and non-natives. When education is examined, individuals who were 
Table 3.3 Relative risk ratios for individuals, 15-29 (unemployed vs employed, and inactive vs employed), Greece and Spain: 2008 and 2015

\begin{tabular}{|c|c|c|c|c|c|c|}
\hline & Factors & Categories & Unemployed & $\begin{array}{l}\text { Std. } \\
\text { errors }\end{array}$ & Inactive & $\begin{array}{l}\text { Std. } \\
\text { errors }\end{array}$ \\
\hline \multirow{8}{*}{$\begin{array}{l}\text { Greece, } \\
2008\end{array}$} & \multirow{6}{*}{$\begin{array}{l}\text { Level of } \\
\quad \text { education } \\
\text { Gender } \\
\text { Nationality } \\
\text { Age groups }\end{array}$} & Low & $3.086^{\circ}$ & 0.053 & $0.834 * *$ & 0.058 \\
\hline & & Medium & $3.819 * * *$ & 0.046 & $0.853^{* *}$ & 0.046 \\
\hline & & Female & $2.487 * * *$ & 0.026 & $2.127 * * *$ & 0.037 \\
\hline & & Non-national & $0.637 * * *$ & 0.044 & $0.599 * * *$ & 0.071 \\
\hline & & $15-19$ & $58.706 * * *$ & 0.029 & $2.571 * * *$ & 0.073 \\
\hline & & $20-24$ & $4.707 * * *$ & 0.043 & $1.867 * * *$ & 0.039 \\
\hline & \multirow{2}{*}{$\begin{array}{l}\text { Degree of } \\
\quad \text { urbanization }\end{array}$} & Rural areas & $0.452 * * *$ & 0.036 & - & - \\
\hline & & $\begin{array}{c}\text { Towns and } \\
\text { suburbs }\end{array}$ & $0.620 * * *$ & 0.039 & - & - \\
\hline \multirow{8}{*}{$\begin{array}{l}\text { Greece, } \\
2015\end{array}$} & \multirow{6}{*}{$\begin{array}{l}\text { Level of } \\
\quad \text { education } \\
\text { Gender } \\
\text { Nationality } \\
\text { Age groups }\end{array}$} & Low & $4.655 * * *$ & 0.071 & $1.244 * * *$ & 0.060 \\
\hline & & Medium & $4.056 * * *$ & 0.055 & - & - \\
\hline & & Female & $1.964 * * *$ & 0.036 & $1.560 * * *$ & 0.035 \\
\hline & & Non-national & $0.631 * * *$ & 0.069 & - & - \\
\hline & & $15-19$ & $100.000 * * *$ & 0.076 & $0.512 * * *$ & 0.091 \\
\hline & & $20-24$ & $17.540 * * *$ & 0.075 & - & - \\
\hline & \multirow{2}{*}{$\begin{array}{l}\text { Degree of } \\
\quad \text { urbanization }\end{array}$} & Rural areas & $0.378 * * *$ & 0.045 & $1.090 *$ & 0.042 \\
\hline & & $\begin{array}{c}\text { Towns and } \\
\text { suburbs }\end{array}$ & $0.703 * * *$ & 0.042 & $1.079 * *$ & 0.042 \\
\hline \multirow{8}{*}{$\begin{array}{l}\text { Spain, } \\
2008\end{array}$} & \multirow{6}{*}{$\begin{array}{l}\text { Level of } \\
\quad \text { education } \\
\text { Gender } \\
\text { Nationality } \\
\text { Age groups }\end{array}$} & Low & $0.804 * * *$ & 0.055 & $1.833 * * *$ & 0.069 \\
\hline & & Medium & $1.515 * * *$ & 0.052 & $1.131 * * *$ & 0.076 \\
\hline & & Female & $1.694 * * *$ & 0.038 & $1.282 * * *$ & 0.050 \\
\hline & & Non-national & $0.775 * * *$ & 0.071 & $1.190 * * *$ & 0.082 \\
\hline & & $15-19$ & $29.000 * * *$ & 0.060 & $3.313^{* * *}$ & 0.075 \\
\hline & & $20-24$ & $3.498 * * *$ & 0.046 & $1.646^{* * *}$ & 0.057 \\
\hline & \multirow{2}{*}{$\begin{array}{l}\text { Degree of } \\
\quad \text { urbanization }\end{array}$} & Rural areas & $0.877 * * *$ & 0.044 & $0.864 * * *$ & 0.057 \\
\hline & & $\begin{array}{c}\text { Towns and } \\
\text { suburbs }\end{array}$ & $0.880 * * *$ & 0.048 & - & - \\
\hline \multirow{7}{*}{$\begin{array}{l}\text { Spain, } \\
2015\end{array}$} & \multirow{6}{*}{$\begin{array}{l}\text { Level of } \\
\quad \text { education } \\
\text { Gender } \\
\text { Nationality } \\
\text { Age groups }\end{array}$} & Low & $0.714 * * *$ & 0.065 & $1.470 * * *$ & 0.069 \\
\hline & & Medium & $0.396 * * *$ & 0.060 & $0.515^{* * *}$ & 0.068 \\
\hline & & Female & $0.725 * * *$ & 0.046 & $0.780 * * *$ & 0.048 \\
\hline & & Non-national & $1.677 * * *$ & 0.092 & $1.533 * * *$ & 0.093 \\
\hline & & $15-19$ & $66.719 * * *$ & 0.088 & $20.919 * * *$ & 0.077 \\
\hline & & $20-24$ & $12.494 * * *$ & 0.084 & $7.510 * * *$ & 0.069 \\
\hline & $\begin{array}{l}\text { Degree of } \\
\quad \text { urbanization }\end{array}$ & Rural areas & $1.176^{* *}$ & 0.054 & - & - \\
\hline
\end{tabular}

Note: $* * * \mathrm{p}<0.0001,{ }^{* *} \mathrm{p}<0.001,{ }^{*} \mathrm{p}<0.01$ (only relative risk ratios corresponding to statistically significant coefficients are included).

Source: EU-LFS data 
medium educated showed an increased risk of being unemployed and not employed $(\mathrm{RRR}=1.515)$. The most important factor for that year was age, with the youngest group being in the vulnerable position of having an almost 30 times higher propensity of being unemployed than those in the age category 25-29. An important change during the years of the crisis was the significant increase in this propensity, with the youngest category exhibiting an almost 66 times greater risk of being unemployed. The situation also deteriorated for the age group 20-24, which had an almost 12.5 times higher chance of being unemployed when compared to those aged 25-29. Young women in 2015 had lower chances of being unemployed, as did young natives compared to young non-natives. Low education played a statistically significant role both in 2008 and 2015 as far as inactivity is concerned. The importance of age increased, with young individuals having an almost 20 times higher propensity towards being inactive if they belonged to the 15-19 age category and a 7.5 times higher propensity towards being inactive if they were aged 20-24. The odds of young individuals being left out of the labour market were higher if they were male in 2015 (RRR=1.269), while for 2008 the opposite trend was observed.

Coming to the last group of countries, the two EFTA member states (Table 3.4), the analysis showed that young people in Norway had a higher propensity towards unemployment when they were low educated $(\mathrm{RRR}=1.701)$ in 2008 , whereas in 2015 low- or medium-educated individuals had better chances of being employed than their highly educated peers. The young people in the age groups 15-19 and 20-24 had a higher risk of being unemployed ( $R R R=4.605$ and $R R R=2.133$, respectively) in 2008, and a slightly higher risk again in 2015 ( $R R R=5.985$ and $R R R=2.809$, respectively) than those aged 25-29. The RRR of non-native young individuals to be employed was higher when compared to young natives in 2015. Additionally, it seems that educational level, nationality and age influenced the odds of being inactive in 2008, while the main predictive factors for being out of the labour force in 2015 were age and nationality, with the younger age groups and non-natives being more exposed to inactivity.

In Switzerland the most important factors influencing unemployment in 2008 were the level of education of the individual, gender and age. Loweducated young people had an RRR of being unemployed equal to 1.553 compared to their highly educated peers. Moreover, young women had a propensity to be unemployed that was almost 1.6 times higher than that of young men. It is noteworthy that the effect of age on the odds of being unemployed was almost identical in 2008 and 2015. In 2015 cities were in a slightly more favourable position in the sense that young individuals living in highly urbanized areas had lower chances of being unemployed 
Table 3.4 Relative risk ratios for individuals, 15-29 (unemployed vs employed, and inactive vs employed), Norway and Switzerland: 2008 and 2015

\begin{tabular}{|c|c|c|c|c|c|c|}
\hline & Factors & Categories & Unemployed & $\begin{array}{l}\text { Std. } \\
\text { Error }\end{array}$ & Inactive & $\begin{array}{l}\text { Std. } \\
\text { Error }\end{array}$ \\
\hline \multirow[t]{5}{*}{$\begin{array}{l}\text { Norway, } \\
2008\end{array}$} & $\begin{array}{l}\text { Level of } \\
\quad \text { education }\end{array}$ & Low & $1.701 * * *$ & 0.138 & $1.707^{*}$ & 0.175 \\
\hline & Gender & Female & - & - & $0.663^{* *}$ & 0.166 \\
\hline & Nationality & Non-national & - & - & $2.150 *$ & 0.108 \\
\hline & Age groups & $15-19$ & $4.605^{* * *}$ & 0.116 & $2.150^{* * *}$ & 0.108 \\
\hline & & $20-24$ & $2.133 * * *$ & 0.104 & $2.180 * * *$ & 0.128 \\
\hline \multirow{5}{*}{$\begin{array}{l}\text { Norway, } \\
2015\end{array}$} & Level of & Low & $0.352 * * *$ & 0.125 & - & - \\
\hline & education & Medium & $0.718^{* * *} *$ & 0.116 & - & - \\
\hline & Nationality & Non-national & $0.692 * *$ & 0.133 & $1.572 *$ & 0.123 \\
\hline & Age groups & $15-19$ & $5.985^{* * *}$ & 0.108 & $2.476 * * *$ & 0.118 \\
\hline & & $20-24$ & $2.809 * * *$ & 0.094 & $1.838 * * *$ & 0.192 \\
\hline \multirow{6}{*}{$\begin{array}{l}\text { Switzerland, } \\
2008\end{array}$} & Level of & Low & $1.553 * * *$ & 0.121 & $1.837 * * *$ & 0.120 \\
\hline & education & Medium & - & - & $1.545^{*}$ & 0.198 \\
\hline & Gender & Female & $1.589 * * *$ & 0.057 & $1.436 * * *$ & 1.107 \\
\hline & Nationality & Non-national & $1.137 * * *$ & 0.057 & $1.919 * * *$ & 0.112 \\
\hline & Age groups & $15-19$ & $5.219 * * *$ & 0.088 & $1.876^{* * *}$ & 0.160 \\
\hline & & $20-24$ & $1.993 * * *$ & 0.069 & $1.557 * * *$ & 0.135 \\
\hline \multirow[t]{6}{*}{$\begin{array}{l}\text { Switzerland, } \\
2015\end{array}$} & $\begin{array}{l}\text { Level of } \\
\text { education }\end{array}$ & Low & $0.665^{* * *}$ & 0.101 & - & - \\
\hline & Nationality & Non-national & $0.909 * * *$ & 0.053 & $1.692 * * *$ & 0.094 \\
\hline & Age groups & $15-19$ & $5.332 * * *$ & 0.088 & $3.373 * * *$ & 0.106 \\
\hline & & $20-24$ & $1.920 * * *$ & 0.069 & $2.038 * * *$ & 0.105 \\
\hline & Degree of & Rural areas & $1.549 * * *$ & 0.065 & - & - \\
\hline & urbanization & $\begin{array}{c}\text { Towns and } \\
\text { suburbs }\end{array}$ & $1.269 * * *$ & 0.050 & - & - \\
\hline
\end{tabular}

Note: $* * * \mathrm{p}<0.0001,{ }^{* *} \mathrm{p}<0.001,{ }^{*} \mathrm{p}<0.01$ (only relative risk ratios corresponding to statistically significant coefficients are included).

Source: EU-LFS data

than those living in rural areas, towns or suburbs. Where inactivity was concerned in 2008, again the level of education of the individual played an important role, in that low- or medium-educated youth had $R R R=1.837$ and $R R R=1.545$, respectively, of being inactive compared to highly educated youth. Women were more exposed to inactivity than men, while age also played an important role $(\mathrm{RRR}=1.876$ and $\mathrm{RRR}=1.557$, respectively, for the age groups 15-19 and 20-24 compared to the age group 25-29). Regarding inactivity in 2015, gender and education were 
not statistically significant. The position of the youngest groups weakened, with the propensity of the 15-19 and 20-24 age groups towards inactivity amounting respectively to almost 3.4 times and 2 times higher compared to the age group 25-29.

\section{THE ROLE OF PARENTAL EDUCATION}

Several studies have suggested that the parental characteristics influencing educational choice do matter (Stamatopoulou et al., 2016), especially during adolescence (Breen and Jonsson, 2005; Erikson and Jonsson, 1996; Jaeger and Holm, 2007), and that parental social status and networks are especially important in early adulthood when young people are entering the labour market (Erola, 2009; Härkönen and Bihagen, 2011).

Here we attempted to examine the effect of parents' education on their offspring's odds of being employed and not unemployed or inactive by performing MLR selecting the young individuals who live with their parent(s), since parental education in the EU-LFS survey is only measured in those cases. Therefore, the analysis concerns individuals who live in the same household as their parent(s). The results of the MLR analysis regarding the effect of parental education on the labour market situation of young people for the years 2008 and 2015 in the examined countries are provided in Tables 3A.1 and 3A.2 (Appendix, this chapter).

In all nine countries the educational achievements of the father/mother did not increase the chances of a young individual being employed and not unemployed in 2008. On the other hand, lower parental education did play a negative role in the chances of a young individual being employed and not inactive in these countries. The opposite situation was observed in 2015 , in the sense that parental education seemed to influence - to a lesser or greater extent - the chances of a young individual being at risk of unemployment in all countries except for Greece. More specifically, in all countries excluding Greece, living with a father or mother with low or medium education affected the propensities towards being employed and not unemployed in a negative way. The exact same was the case for the chances of a young person being inactive and not employed. Thus, higher parental education influenced their offspring's odds of being employed and not inactive in a positive manner. The findings, therefore, suggest a growing importance of social background and social capital - with the exception of Greece. 
Table 3.5 Key factors explaining youth unemployment (unemployed vs employed) and changes between 2008 and 2015

\begin{tabular}{|c|c|c|c|c|}
\hline & & 2008 & 2015 & $\begin{array}{l}\text { Direction } \\
\text { of change }\end{array}$ \\
\hline \multicolumn{5}{|l|}{ Bulgaria } \\
\hline \multirow[t]{2}{*}{ Education } & Low vs High & + & + & $\uparrow$ \\
\hline & Medium vs High & + & + & $\uparrow$ \\
\hline Gender & Females vs Males & + & - & $\leftrightarrow$ \\
\hline \multirow[t]{2}{*}{ Age } & $15-19$ vs $25-29$ & + & + & $\simeq$ \\
\hline & $20-24$ vs $25-29$ & + & + & $\uparrow$ \\
\hline \multirow[t]{2}{*}{ Urbanization } & Rural areas vs Cities & - & + & $\leftrightarrow$ \\
\hline & Towns and suburbs vs Cities & - & + & $\leftrightarrow$ \\
\hline \multicolumn{5}{|l|}{ Czech Republic } \\
\hline \multirow{2}{*}{ Education } & Low vs High & + & - & $\leftrightarrow$ \\
\hline & Medium vs High & & + & \\
\hline Gender & Females vs Males & + & - & $\leftrightarrow$ \\
\hline Nationality & Non-nationals vs Nationals & - & + & $\leftrightarrow$ \\
\hline \multirow[t]{2}{*}{ Age } & $15-19$ vs $25-29$ & + & + & $\uparrow \uparrow$ \\
\hline & $20-24$ vs $25-29$ & + & + & $\uparrow \uparrow$ \\
\hline \multirow[t]{2}{*}{ Urbanization } & Rural areas vs Cities & - & & \\
\hline & Towns and suburbs vs Cities & - & & \\
\hline \multicolumn{5}{|l|}{ Germany } \\
\hline \multirow[t]{2}{*}{ Education } & Low vs High & + & - & $\leftrightarrow$ \\
\hline & Medium vs High & + & - & $\leftrightarrow$ \\
\hline Gender & Females vs Males & + & - & $\leftrightarrow$ \\
\hline Nationality & Non-nationals vs Nationals & + & - & $\leftrightarrow$ \\
\hline \multirow[t]{2}{*}{ Age } & $15-19$ vs $25-29$ & + & + & $\uparrow$ \\
\hline & $20-24$ vs $25-29$ & + & + & $\uparrow \uparrow$ \\
\hline \multirow[t]{2}{*}{ Urbanization } & Rural areas vs Cities & - & + & $\leftrightarrow$ \\
\hline & Towns and suburbs vs Cities & - & + & $\leftrightarrow$ \\
\hline \multicolumn{5}{|l|}{ Greece } \\
\hline \multirow[t]{2}{*}{ Education } & Low vs High & + & + & $\uparrow$ \\
\hline & Medium vs High & + & + & $\uparrow$ \\
\hline Gender & Females vs Males & + & + & $\downarrow$ \\
\hline \multirow{3}{*}{$\begin{array}{l}\text { Nationality } \\
\text { Age }\end{array}$} & Non-nationals vs Nationals & - & - & $\simeq$ \\
\hline & $15-19$ vs $25-29$ & + & + & $\uparrow \uparrow$ \\
\hline & $20-24$ vs $25-29$ & + & + & $\uparrow \uparrow$ \\
\hline \multirow[t]{2}{*}{ Urbanization } & Rural areas vs Cities & - & - & $\simeq$ \\
\hline & Towns and suburbs vs Cities & - & - & $\simeq$ \\
\hline \multicolumn{5}{|l|}{ Norway } \\
\hline \multirow[t]{2}{*}{ Education } & Low vs High & + & + & $\downarrow$ \\
\hline & Medium vs High & & - & \\
\hline Nationality & Non-nationals vs Nationals & & - & \\
\hline \multirow[t]{2}{*}{ Age } & $15-19$ vs $25-29$ & + & + & $\uparrow$ \\
\hline & $20-24$ vs $25-29$ & + & + & $\uparrow$ \\
\hline
\end{tabular}


Table 3.5 (continued)

\begin{tabular}{|c|c|c|c|c|}
\hline & & 2008 & 2015 & $\begin{array}{l}\text { Direction } \\
\text { of change }\end{array}$ \\
\hline \multicolumn{5}{|l|}{ Poland } \\
\hline \multirow[t]{2}{*}{ Education } & Low vs High & + & - & $\leftrightarrow$ \\
\hline & Medium vs High & + & - & $\leftrightarrow$ \\
\hline Gender & Females vs Males & + & - & $\leftrightarrow$ \\
\hline Nationality & Non-nationals vs Nationals & + & - & $\leftrightarrow$ \\
\hline \multirow{2}{*}{ Age } & $15-19$ vs $25-29$ & + & + & $\uparrow \uparrow$ \\
\hline & $20-24$ vs $25-29$ & + & + & $\uparrow \uparrow$ \\
\hline \multirow[t]{2}{*}{ Urbanization } & Rural areas vs Cities & - & + & $\leftrightarrow$ \\
\hline & Towns and suburbs vs Cities & - & + & $\leftrightarrow$ \\
\hline \multicolumn{5}{|l|}{ Spain } \\
\hline \multirow[t]{2}{*}{ Education } & Low vs High & - & - & $\downarrow$ \\
\hline & Medium vs High & + & - & $\leftrightarrow$ \\
\hline Gender & Females vs Males & + & - & $\leftrightarrow$ \\
\hline Nationality & Non-nationals vs Nationals & - & + & $\leftrightarrow$ \\
\hline \multirow[t]{2}{*}{ Age } & $15-19$ vs $25-29$ & + & + & $\uparrow \uparrow$ \\
\hline & $20-24$ vs $25-29$ & + & + & $\uparrow \uparrow$ \\
\hline \multirow[t]{2}{*}{ Urbanization } & Rural areas vs Cities & - & + & $\leftrightarrow$ \\
\hline & Towns and suburbs vs Cities & - & & \\
\hline \multicolumn{5}{|l|}{ Switzerland } \\
\hline Education & Low vs High & + & - & $\leftrightarrow$ \\
\hline Gender & Females vs Males & + & & \\
\hline Nationality & Non-nationals vs Nationals & + & - & $\leftrightarrow$ \\
\hline \multirow[t]{2}{*}{ Age } & $15-19$ vs $25-29$ & + & + & $\simeq$ \\
\hline & $20-24$ vs $25-29$ & + & + & $\simeq$ \\
\hline \multirow[t]{2}{*}{ Urbanization } & Rural areas vs Cities & & + & \\
\hline & Towns and suburbs vs Cities & & + & \\
\hline \multicolumn{5}{|l|}{ UK } \\
\hline \multirow[t]{2}{*}{ Education } & Low vs High & + & - & $\leftrightarrow$ \\
\hline & Medium vs High & + & - & $\leftrightarrow$ \\
\hline Gender & Females vs Males & + & - & $\leftrightarrow$ \\
\hline Nationality & Non-nationals vs Nationals & - & - & $\downarrow$ \\
\hline \multirow[t]{2}{*}{ Age } & $15-19$ vs $25-29$ & + & + & $\uparrow \uparrow$ \\
\hline & $20-24$ vs $25-29$ & + & + & $\uparrow \uparrow$ \\
\hline \multirow[t]{2}{*}{ Urbanization } & Rural areas vs Cities & - & + & $\leftrightarrow$ \\
\hline & Towns and suburbs vs Cities & - & + & $\leftrightarrow$ \\
\hline
\end{tabular}

Notes: $\quad+$ denotes $\mathrm{RRR} \geq 1$; - denotes $\mathrm{RRR}<1$; $\uparrow$ denotes an increase in the respective $\mathrm{RRR} ; \downarrow$ denotes a decrease in the respective $\mathrm{RRR} ; \simeq$ denotes that the RRR remained approximately the same; $\uparrow \uparrow$ denotes a sharp increase in the RRR (i.e., the RRR in 2015 was more than 1.5 times the respective RRR in 2008); and $\leftrightarrow$ denotes a reversed influence of the factor.

Source: EU-LFS data 


\section{CONCLUSIONS}

In this chapter we have examined individual-level factors influencing youth unemployment and inactivity in nine European countries. More specifically, gender, educational attainment, nationality, age, the respective region's degree of urbanization and parental education were used as independent variables in an MLR model in order to explain youth unemployment and inactivity.

Overall, the effect of these demographic factors changed in the period from 2008 to 2015 in most countries. The only factor identified as a determinant for both years and in all countries and whose negative effect increases is that of belonging in the younger age groups, that is, 15-19 and 20-24, as opposed to the older group of young people (aged 25-29).

Low educational attainment played an important role for young people in these nine countries in 2008, but not as important as in 2015 in most countries. Countries where low education is crucial in decreasing the chances of a young individual being employed in 2015 are Bulgaria, Greece and Spain. It is worth mentioning that low education was also found to be a key determinant for youth unemployment and inactivity in the respective nine countries in 2013, based on EU-LFS data (Karamessini et al., 2016b).

When gender is examined, it emerges that young women were in a more vulnerable situation than young men in 2008 in most countries, except for Norway and Switzerland. The crisis mainly hit occupations considered to be 'male', so while the EU strategic engagement for gender equality might have had an impact on labour market policies in these countries, ${ }^{14}$ the situation was partially reversed in 2015 , with young women remaining in a weaker position than young men only in Greece.

As far as the degree of urbanization is concerned, living in a city and not in a rural area or a town/suburb produced higher chances of being unemployed in 2008 in all countries except for Norway and Switzerland. This changed during the years of the crisis, with cities remaining in a worse position than areas with a lower degree of urbanization in 2015 only in Greece. Taking into account all the individual-level factors examined, it is apparent that Greece is a special case in some respects.

Finally, an important finding is the growing importance of social background and social capital for those living in the same household as their mother or father. In 2015 parental education had a positive influence on the labour market situation of young people (living with their parent[s]),

14 http://ec.europa.eu/newsroom/document.cfm?doc_id=43416 (assessed 8 May 2018). 
whereas the effect was not as strong in 2008. However, the fact that this variable concerns only those who still live in the parental household means that no general assumptions are possible regarding the diachronic effect of social capital on young people's propensity towards unemployment or inactivity.

In general, it seems that apart from the younger age categories, the crisis has not affected the impact of sociodemographic factors on youth unemployment and inactivity unequivocally. Even if in some cases (low) education seems to play a negative role, this has not been proven to be a constantly aggravating tendency in all examined countries. In this sense, policies combatting early job insecurity should consider national (and to some extent even local) specificities regarding both the intensity and the extension of the crisis and its remedies. Evidence-based policymaking calls for increased concern for younger individuals and their integration into the labour market, however in differentiated ways from country to country and insisting on relevant sociodemographic characteristics and structural constraints.

Table 3.5 sums up the conclusions of the analysis and presents the various factors' direction of influence.

\section{REFERENCES}

Bell DN and Blanchflower DG (2011) Young people and the Great Recession. Oxford Review of Economic Policy 27(2): 241-67.

Brada JC, Marelli E and Signorelli M (2014) Young people and the labor market: Key determinants and new evidence. Comparative Economic Studies 56(4): 556-66.

Breen R and Jonsson JO (2005) Inequality of opportunity in comparative perspective: Recent research on educational attainment and social mobility. Annual Review of Sociology 31: 223-43.

Bruno GSF, Marelli E and Signorelli M (2014) The rise of NEET and youth unemployment in EU regions after the crisis. Comparative Economic Studies 56(4): 592-615.

Chung H, Bekker S and Houwing H (2012) Young people and the post-recession labour market in the context of Europe 2020. European Review of Labour and Research 18(3): 301-17.

Dănăcică D-E (2015) Youth (re) employment probability in Romania. Procedia Economics and Finance 22: 148-53.

Eichhorst W, Hinte H and Rinne U (2013) Youth unemployment in Europe: What to do about it? IZA Policy Paper no. 65. Bonn: Institute for the Study of Labor.

Erikson R and Jonsson JO (eds) (1996) Can Education be Equalized? The Swedish Case in Comparative Perspective. Boulder, CO: Westview Press.

Erola J (2009) Social mobility and education of Finnish cohorts born 1936-75. Succeeding while failing in equality of opportunity? Acta Sociologica 52(4): 307-27. 
Eurofound (2014) Mapping Youth Transitions in Europe. Luxembourg: Publications Office of the European Union.

Härkönen J and Bihagen E (2011) Occupational attainment and career progression in Sweden. European Societies 13(3): 451-79.

Jaeger MM and Holm A (2007) Does parents' economic, cultural, and social capital explain the social class effect on educational attainment in the Scandinavian mobility regime? Social Science Research 36: 719-44.

Karamessini M, Symeonaki M and Stamatopoulou G(2016a) The role of the economic crisis in determining the degree of early job insecurity in Europe. NEGOTIATE Working Paper no. 3.3. https://negotiate-research.eu/files/2015/04/NEGOTIATEworking-paper-D3.3.pdf (accessed 15 June 2018).

Karamessini M, Symeonaki M, Stamatopoulou G and Papazachariou A (2016b) The careers of young people in Europe during the economic crisis: Identifying risk factors. NEGOTIATE Working Paper no. 3.2. https://negotiate-research.eu/files/2015/04/ NEGOTIATE-working-paper-no-D3.2-The-careers-of-young-people-in-Eurpaduring-the-economic-crisis.pdf (accessed 15 June 2018).

Msigwa R and Kipesha EF (2013) Determinants of youth unemployment in developing countries. Journal of Economics and Sustainable Development 4(14): 67-77.

OECD (2010) Off to a Good Start? Jobs for Youth. Paris: OECD.

O'Higgins N (2010) The impact of the economic and financial crisis on youth employment: Measures for labour market recovery in the European Union, Canada and the United States. ILO Working Paper no. 462129. Geneva: International Labour Organization.

O'Higgins N (2012) This time it's different? Youth labour markets during 'The Great Recession'. Comparative Economic Studies 54(2): 395-412.

O’Reilly J, Eichhorst W, Gábos A, Hadjivassiliou K, Lain D, Leschke J, McGuinness S, Mýtna Kureková L, Nazio T, Ortlieb R, Russell H and Villa P (2015) Five characteristics of youth unemployment in Europe: Flexibility, education, migration, family legacies, and EU policy. SAGE Open 5(1): 1-19. DOI: $10.1177 / 2158244015574962$.

Plantenga J, Remery C, and Lodovici MS (2013) Starting Fragile: Gender Differences in the Youth Labour Market. Luxembourg: Publications Office of the European Union.

Sigle-Rushton W and Perrons D (2013) Employment transitions over the life cycle: A statistical analysis. Working Paper no. 46. Manchester, UK: Equal Opportunities Commission.

Stamatopoulou G, Symeonaki M and Michalopoulou C (2016) Occupational and educational gender segregation in Southern Europe. In: Bozeman J, Oliveira T and Skiadas CH (eds) Stochastic and Data Analysis Methods and Applications in Statistics and Demography. Athens: ISAST, pp.611-19.

Symeonaki M and Filopoulou C (2017) Quantifying gender distances in education, occupation and unemployment. Equality, Diversity and Inclusion: An International Journal 36(4): 340-61.

Symeonaki M, Karamessini M and Stamatopoulou G (forthcoming a) Genderbased differences on the impact of the economic crisis on labour market flows in Southern Europe. In: Bozeman J and Skiadas C (eds) Data Analysis and Applications: New and Classical Approaches. London: ISTE Science Publishing.

Symeonaki M, Karamessini M and Stamatopoulou G (forthcoming b) Measuring school-to-work transition probabilities in Europe with evidence from the 
EU-SILC. In: Bozeman J and Skiadas C (eds) Data Analysis and Applications: New and Classical Approaches. London: ISTE Science Publishing.

Symeonaki M, Stamatopoulou G and Karamessini M (2017) Labour market flows in Europe: Evidence from the EU-LFS. Conference Paper. London, UK: ASMDA, 6-9 June.

Van Ours J (2015) The Great Recession was not so great. Labour Economics 34: $1-12$. 


\section{APPENDIX}

Table 3A.1 RRR for individuals 15-29 (unemployed vs employed, and inactive vs employed), 2008

\begin{tabular}{lcccc}
\hline & Unemployed & Std. errors & Inactive & Std. errors \\
\hline $\begin{array}{l}\text { Bulgaria } \\
\text { Level of education of father }\end{array}$ & & & & \\
$\quad$ Low & $0.601^{* * *}$ & 0.121 & $2.024 * * *$ & 0.118 \\
$\quad$ Medium & $0.693^{* * *}$ & 0.103 & - & - \\
Level of education of mother & & & & \\
$\quad$ Low & $0.660^{* * *}$ & 0.102 & $2.469^{* * *}$ & 0.165 \\
$\quad$ Medium & $0.679^{* * *}$ & 0.086 & - & - \\
Czech Republic & & & & \\
Level of education of father & & & & \\
$\quad$ Low & $0.319^{* * *}$ & 0.072 & $3.575^{* * *}$ & 0.170 \\
$\quad$ Medium & $0.480^{* * *}$ & 0.041 & - & - \\
Level of education of mother & & & & \\
$\quad$ Low & $0.259^{* * *}$ & 0.055 & $3.980^{* * *}$ & 0.184 \\
$\quad$ Medium & $0.469^{* * *}$ & 0.044 & $1.475^{* * *}$ & 0.178
\end{tabular}

Germany

Level of education of father

Low

Medium

Level of education of mother

Low

Medium

Greece

Level of education of father

Low

Medium

Level of education of mother

Low

Medium

$0.518 * * *$

0.127

$2.217 * * *$

0.109

$0.532 * * *$

0.079

$0.497 * * *$

0.103

$0.552 * * *$

0.085

$0.552 * * *$

0.105

Poland

Level of education of father
Low
$0.316^{* * *}$
0.059
Medium
$0.542 * * *$
0.052
Level of education of mother
Low

$\begin{array}{ll}0.307 * * * & 0.049 \\ 0.487 * * * & 0.043\end{array}$
Medium

$1.487 * * *$

0.148

$1.382 * * *$

0.139 
Table $3 A .1$ (continued)

\begin{tabular}{lcccc}
\hline & Unemployed & Std. errors & Inactive & Std. errors \\
\hline $\begin{array}{l}\text { Spain } \\
\text { Level of education of father }\end{array}$ & & & & \\
$\quad$ Low & $0.442^{* * *}$ & 0.047 & $1.255^{* * *}$ & - \\
$\quad$ Medium & $0.756^{* * *}$ & 0.060 & - & - \\
$\quad$ Level of education of mother & & & & - \\
$\quad$ Low & $0.328^{* * *}$ & 0.049 & - & - \\
$\quad$ Medium & $1.699^{* * *}$ & 0.063 & - & \\
UK & & & & \\
Level of education of father & & & & 0.106 \\
$\quad$ Low & $0.780^{* * *}$ & 0.052 & $1.466^{* * * *}$ & \\
$\quad$ Medium & $0.571^{* * *}$ & 0.047 & $1.055^{* * *}$ & 0.100 \\
$\quad$ Level of education of mother & & & & \\
$\quad$ Low & $0.773^{* * *}$ & 0.042 & $1.467^{* * * *}$ & 0.082 \\
$\quad$ Medium & $0.775^{* * *}$ & 0.042 & $1.154^{* * *}$ & 0.085 \\
\hline
\end{tabular}

Notes: $\quad * * * \mathrm{p}<0.0001,{ }^{* *} \mathrm{p}<0.001,{ }^{*} \mathrm{p}<0.01$ (only RRR corresponding to statistically significant coefficients are included).

Source: Authors' calculations, EU-LFS data, 2008. 
Table 3A.2 RRR for individuals 15-29 (unemployed vs employed, and inactive vs employed), 2015

\begin{tabular}{lcccr}
\hline & Unemployed & Std. Error & Inactive & Std. Err \\
\hline $\begin{array}{l}\text { Bulgaria } \\
\text { Level of education of father }\end{array}$ & & & & \\
$\quad$ Low & $1.950^{* * *}$ & 0.163 & $3.670^{* * *}$ & 0.305 \\
$\quad$ Medium & $2.136^{* * *}$ & 0.146 & $2.100^{* * *}$ & 0.295 \\
Level of education of mother & & & & \\
$\quad$ Low & $1.429^{* * *}$ & 0.128 & $3.886^{* * * *}$ & 0.234 \\
$\quad$ Medium & $1.710^{* * *}$ & 0.109 & $1.864^{* * *}$ & 0.231
\end{tabular}

Czech Republic

Level of education of father

Low

$1.661 * * *$

0.239

$4.617 * * *$

0.447

Medium

$2.181 * * *$

0.107

$2.247 * * *$

0.292

Level of education of mother

Low

$1.876^{* * *}$

0.171

$3.954 * * *$

0.348

Medium

$1.847 * * *$

0.102

$1.965^{* * *}$

0.263

Germany

Level of education of father

Low

$1.535^{* * *}$

0.038

$3.805^{* * *}$

0.108

Medium

$1.185^{* * *}$

0.026

$2.563^{* * *}$

0.090

Level of education of mother

Low

$2.033^{* * *}$

0.036

$4.195^{* * *} \quad 0.102$

Medium

$2.161 * * *$

0.030

$2.036 * * *$

0.098

Greece

Level of education of father

Low

$0.404^{* * *}$

0.048

$1.154 * *$

0.062

Medium

$0.744 * * *$

0.051

Level of education of mother

Low

$0.255^{* * *}$

0.050

Medium

$0.547 * * *$

0.050

Poland

Level of education of father

Low

$3.409 * * *$

0.057

$3.945^{* * *}$

0.109

Medium

$2.516^{* * *}$

0.048

$2.830 * * *$

0.096

Level of education of mother

Low

$2.730 * * *$

0.043

$3.888 * * *$

0.078

Medium

$2.185^{* * *}$

0.034

$2.418 * * *$

0.066

Spain

Level of education of father

$$
\text { Low }
$$


Table 3 A.2 (continued)

\begin{tabular}{lcccc}
\hline & Unemployed & Std. Error & Inactive & Std. Error \\
\hline $\begin{array}{l}\text { Medium } \\
\text { Level of education of mother }\end{array}$ & $1.503^{* * *}$ & 0.069 & $1.545^{* * *}$ & 0.085 \\
$\quad$ Low & $2.520^{* * *}$ & 0.053 & $3.202^{* * *}$ & 0.062 \\
$\quad$ Medium & $1.699^{* * *}$ & 0.063 & $1.610^{* * *}$ & 0.076 \\
UK & & & & \\
Level of education of father & & & & \\
$\quad$ Low & $1.504^{* * *}$ & 0.079 & $1.587 * * *$ & 0.167 \\
$\quad$ Medium & $1.507^{* * *}$ & 0.070 & $1.409^{* * *}$ & 0.154 \\
$\quad$ Level of education of mother & & & & \\
$\quad$ Low & $1.180^{* * *}$ & 0.064 & $1.715^{* * *}$ & 0.122 \\
$\quad$ Medium & $1.384 * * *$ & 0.060 & - & - \\
\hline
\end{tabular}

Notes: $\quad * * * \mathrm{p}<0.0001,{ }^{* *} \mathrm{p}<0.001,{ }^{*} \mathrm{p}<0.01$ (only RRR corresponding to statistically significant coefficients are included).

Source: Authors' calculations. EU-LFS data, 2015. 